\title{
TROPICAL SPASTIC PARAPARESIS IN NORTHEASTERN BRAZIL
}

\author{
C. M. DE CASTRO COSTA * - M. R. SALGUEIRO** - H. CARTON*** \\ O. C. DO VALE** - A. M, DE ARRUDA**
}

SUMMARY - Ten possible cases of tropical spastic paraparesis (TSP) in Northeastern Brazil (Ceará) are presented. They show the typical symptoms and signs of TSP consisting of weakness of the lower limbs, spastic gait, hiperreflexia, bladder dysfunction and variable signs of posterior columns impairment. The laboratory examinations excluded other compressive, infective, degencrative or demyelinating lesions of their spinal cord. Our patients age ranged from 21 to 59 years, all were of black origin and all were of lower social class. There was a slight preponderance of females. An etiological implication of a retrovirus (HTLV-I) has been shown for TSP, but for lack of technical conditions we could not determine it in our patients, and that stands as our subsequent step in those and further cases.

\section{Pariparesia espástica tropical no Nordeste do Brasil.}

RESUMO - Os autores apresentam 10 casos de provável paraparesia espástica tropical (PET) oriunđos do Nordeste do Brasil (Hospital das Clínicas - Universidade Federal do Ceará). Os sintomas consisten de fraqueza dos membros inferiores, marcha espástica, hiperreflexia, disfunção esfincteriana e sinaił variados de distúrbio proprioceptivo. Outras etiologias de mielopatias forum excluidas pelos exames complementares, A idade dos pacientes ia de 21 a 59 anos, todos eram da raca negra e havia discreto predomínio de mulheres. Recentemente, tcm-se atribuido ao retrovirus HTLV-I a etiologia da PET. Por falta de condiçóes técnicas ainda nāo pudemos determiná-la em nossos pacientes.

Tropical myelopathies have interested clinicians and researchers since long time 14,18-20. Those cases have been reported from different countries such as India 9,10 . Seychelles Islands 8, Zaire 1, South Africa 2, Jamaica 5, Colombia 15,16,23, Martinique 21, and Peru 7. Clinically, tropical spastic paraparesis (TSP) consists of a chronic and progressive weakness with spasticity predominantly of the lower limbs with slight impairment of the proprioception 14. Etiologically, this disease was attributed to possibly malnutrition, toxins, treponemal agents, or parasites 13,14 , and more recently to a retrovirus (HTLV-1) in the cases from Caribbean, South America and Africa 5,6,12,17,22.

From a perusal of the literature, no cases seem to have been reported from Brazil. Since, our interest in presenting some of such cases.

\section{CASUISTICS AND METHODS}

Ten patients attending to an University Hospital (Fortaleza-Ceará-Brazil) were studied and investigated along several months. Every one was hospitalized for specialized exams and after the definition of the diagnosis they have been followed up as out-patients.

* Frum the Department of Physiology and Service of Neurology, University Hospital, Federal University of Ceara (UH,FUC), Brazil; ** from the Service of Neurology, UH,FUC); ** from the Department of Neurology, Catholique University of Louvain, Belgium. 
To define the diagnosis of TSP the following criteria suggested in previous papers (16) have been adopted: 1 . No history of difficulty walking or running during school age, combined with two or more of the following items, within two years of onset: (a) increased urinary frequency, nocturia, or retention with or without penile imjotence: (b) leg cramps and/or low back nain: (c) symmetricai weakness of the legs within 6 months of the onset of the disease: and (d) complaints of numbness or dysaesthesiae of legs and feet. 2. Clinical Examination demonstrating increased patellar reflexes, spasticity of hoth legs (usually man:fested by spastic gait) and absence of a sensory level, pupillary abnormalities and/or optic disc changes. 3. No history of relanses.

Besides these criteria, our TSP patients should not present fasciculations and pronounced muscle atrophy of the extremities, as well as they should have a normal myelogram and spinal fluid, the stools and rectal biopsy should not reveal Schistosoma mansoni and their cranio-cervical radiography should exclude basilar impression, a common pathology in our region. All patients live in the Northeast of Brazil, in the State of Ceari, that lies 4-6o south to Equatcr, and has a tropical oceanic climate with rrregular rain periods and long periods of sunlight. This is one of the poorest areas of Brazil with a significant degree of infantile mortality.

\section{RESULTS}

The 10 patients, aged from 21 to 59 (mean of 42.3 ) years, were all black (10/to), predominantly females, and most of them from peasant origin (Table 1).

The principal symptoms of these patients were weakness of the legs, complaints of dysaesthesiae or numbness of the legs and feet, low back pain, increased urinary frequency and less frequently impotence and legs cramps. No history of difficulty walking or running during school age has been reported in those patients. Neurologically they presented spasticity and hiperreflexia of the lower limbs and, in some cases, of the upper limbs and a spastic gait. They had absence of a sensory level and $m$ no case there were pupillary abnormalities, optic disc changes, history or relapses or presence of fasciculations and muscle atrophy (Table 2). Up to now their disease has an evolution from 1 to 8 years (mean: 4 years) (Table 1).

\begin{tabular}{|c|c|c|c|c|c|c|c|}
\hline \multicolumn{2}{|c|}{ Patients } & Ayge & $\operatorname{Sex}$ & Race & Origin & Profession & $\begin{array}{l}\text { Time of } \\
\text { evolution }\end{array}$ \\
\hline I & JGS & 59 & $F$ & Black & S. Gonçalo & - & 6 years \\
\hline II & AMPC & 21 & $F^{\prime}$ & Black & S. Gunçalo & Housewife & 5 years \\
\hline III & PSM & 54 & $\mathbf{M}$ & Black & Fortaleza & Builder & 8 year's \\
\hline IV & PRF & 30 & $\mathbf{M}$ & Black & Jaguaribe & Peasant & 1 year \\
\hline $\mathrm{V}$ & $\mathrm{FCR}$ & 50 & $F$ & Black & Fortaleza & Housewife & 2 years \\
\hline VI & MNF & 48 & $F$ & Black & Fortaleza & Dressmaker & 5 years \\
\hline VII & SAL & 44 & $F$ & Black & Quixeramobim & Housewife & 2 years \\
\hline VIII & MJRS & 33 & $F$ & Black & Fortaleza & Teacher & 3 years \\
\hline IX & RPS & 49 & $\mathbf{M}$ & Black & Aratuba & Peasant & 6 years \\
\hline $\mathrm{X}$ & MAFS & 35 & $\mathbf{F}$ & Black & Campina Grande & Housewife & 2 years \\
\hline
\end{tabular}

Tuble 1 - Tropicul spastis puraparesis in Northesstern Brazil: epidemiological aspects.

The different exams carried out in our patients showed a normal myelogram, a normal CSF and electrophoresis, and negative serological tests for syphilis in serum and CSF. The schistosomiasis research, performed in some of the patients, was negative. The vitamin $B_{12}$ estimation and serum folate levels were not determined. The cranio-cervical radiograms were normal. 


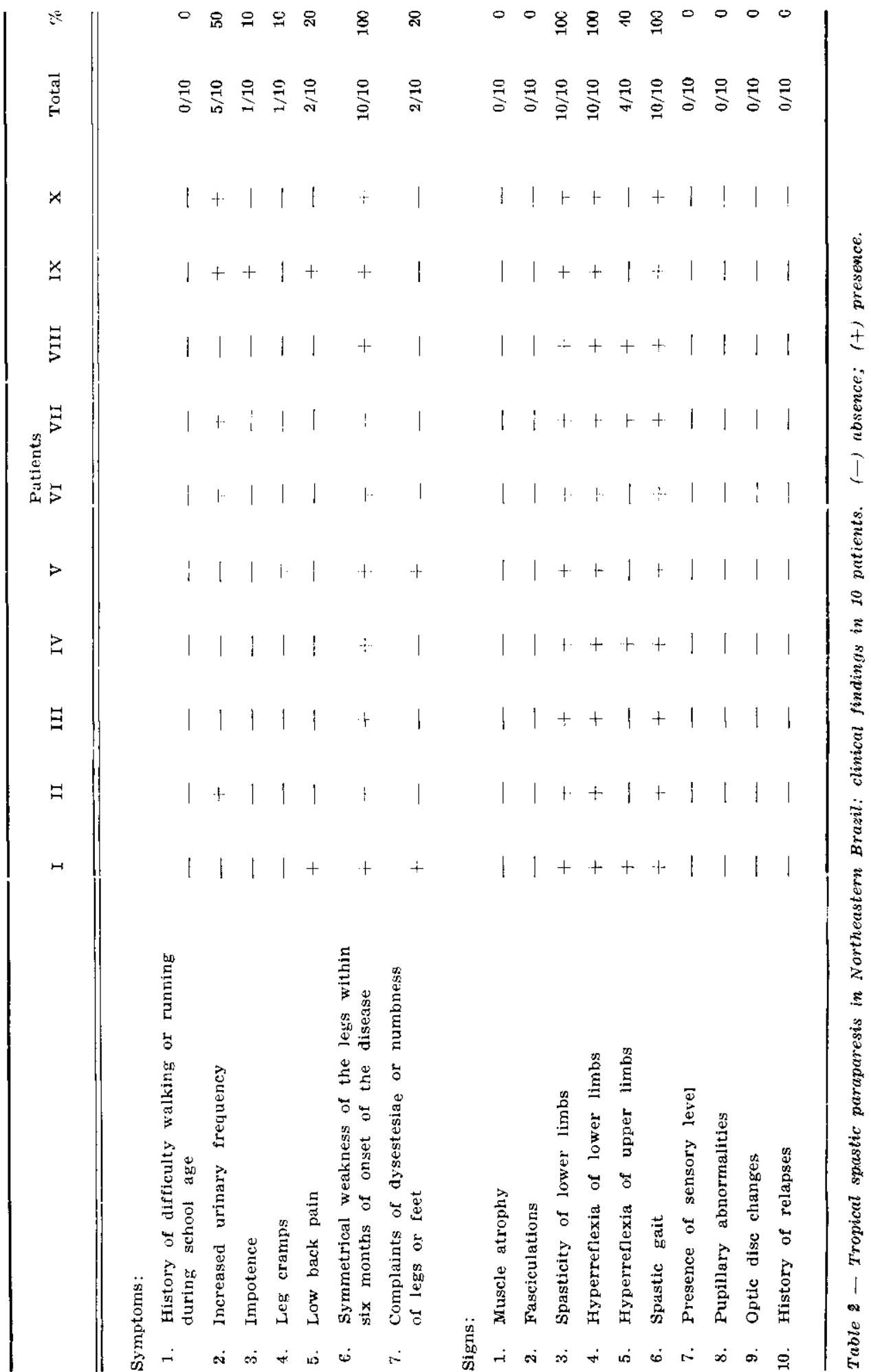




\section{COMMENTS}

The diagnosis of TSP has been suggested in those 10 cases since none of them had a familial history of difficulty running, sensory level, pupillary abnormalities and optic disc changes, fasciculations or muscle atrophy. All present a symmetrical weakness of the legs combined in a variable fashion with bladder dysfunction, low back pain and complaints of dysaesthesia of the feet and all of them had normal myelogram and spinal fluid, negative tests for syphilis and schistosomiasis and normal cranio-cervical radiograms.

All patients were of black African ancestry similar to other studies presented 12 , and there was a slight preponderance of females such as in the samples of Martinique 22 and Seychelles 13 . The mean age of the patients was 42.3 years as in other series. The patients were all native and there is no history of migration. They are of Jower social class and there was no report of other similar cases in their families. The ten patients possibly have subclinical malnutrition as in the general population of that social class and none of them had stigmata of severe malnutrition which could be etiologically related with their syndrome. They had not been exposed to toxins; factors such as habits, housing, occupation, farming and pet were irrelevant for their disease as compared with other neurological patients. Our cases represent a sample of continental origin unlike those of insular character described 12 , but it agrees with the proximity of Ceará to the Equator, the similarity of tropical oceanic climate with long hours of sunlight and little seasonal changes. Our cases are clinically similar to those described in other parts of the world 12,14 , and in none of them retrobulbar neuropathy and deafness occurred as in respectivelly $15 \%$ and $7 \%$ of the cases of Jamaica 12. All cases evolved insidiously unlıke the acute cases described in Zaire 1. All patients presented hyperreflexia and signs of neuropathy were absent in them.

Since these patients are still alive no neuropathological examination has been performed. It is known, from some few cases studied, that the most neuropathological reatures of TSP are a widespread chronic meningoencephalomyelitis and the presence of demyelination, axonal loss in the posterior columns and of the pyramidal tracts 11. Laboratory examinations did not show consistent and typical abnormalities in patients with TSP. All examinations allowed to exclude other spinal cord diseases such as multiple sclerosis, with low frequency in the tropics, tumors, infections of other origin, motor neuron disease and basilar impression. We were also aware for those myelopathies of parasitic origin as that due to Schistosoma mansont. This disease is not rare in our country and is one of the important causes of myelopathies 4.

Since the report of Gessain and associates 5 , the presence of anti-HTLV-I antibodies has been showed in serum and CSF of TSP patients from different countries of South America, Caribbean and Africa, so that this retrovirus outstands as an important etıological agent. Due to regional technical impossibility, we could not pertorn those tests in our patients and it stands as the folowing step in our research witu 'IS patients in Brazil, with eventual international techncal cooperation.

\section{REFERENCES}

1. Carton H, Kayembe K, Kabeya N, Odio, Biliau A, Maertens K - Eprdemic spastic paraparesis in Bandundu (Zaire). J Neurol Neurosurg rsychiat 49:620, iuoti.

2. Cosnett JE - Unexplained spastic myelopathy: 41 cases in a non-european hospital. S Afr Med J $39: 592,1965$.

3. Cruickshank EK - A neuropathic syndrome of uncertain origin. West Indian Med J $5: 147,1956$.

4. Galvão ACR - Radiculomielopatias esquistossomóticas. Arq Bras Neurucirur'gr 1:133, 1985.

5. Gessain A, Barin F, Vermant JC, Gout O, Maurs L, Calender A, de-Thé C - Antibodies to human T-Lymphotropic virus type-I in patients with tropical spastic paraparesis. Lancet 2:407, 1985.

6. Gessain A, Francis H, Sonan T, Giordano C, Akani F, Piquemal M, Claudie C, Malone G, Essex M, de-Thé G - HTLV-I and tropical spastic paraparesis in Africa, Lancet $2: 698,1986$. 
7. Johnson RT, Griffin DE, Arregui A, Mora C, Gibbs CJ, Cuba JM, Trelles L, Vaisberg A - Spastic paraparesis and HTLV-I infection in Peru. Ann Neurol 23 (suppl): S.151, 1988.

8. Kelly $R$, De Mol B - Paraplegta in the islands of the Indian Ocean. Afr $J$ Neurol Sci $1: 5,1982$.

9. Mani KS - Neurological disease in South India. In Spillane JD (ed): Tropical Neurology. Oxtord University Press, London, 1973, pg 78.

10. Mani KS, Mani AJ, Montgomery RD - A spastic paraplegic syndrome in South India. J Neurol Sici 9:179, 1969.

11. Picardo P, Ceroni M, Rodgers-Johnson P, Mora C, Ascher DM, Char G, Gibbs CJ and Gajdusek DC - Pathological and immunological observations on tropical spastic paraparesis in patients from Jamaica. Ann Neurol 23 (suppl): S.156, 1988.

12. Roman GC - The neuroepidemiology of tropical spastic paraparesis. Ann Neurol 23 (suppl): S.113, 1988.

13. Roman GC, Spencer PS, Schoenberg BS, Hugon J, Ludolph A, Rodgers-Johnson P, Osuntokun BO, Shamlaye CF - Tropical spastic paraparesis in the Seychelles islands: a clinical and case-control neuroepidemiological study. Neurology 37:1323, 1987.

14. Roman GC, spencer PS, Schoenberg BS - Tropical myeloneuropathies: the hidden indemias. Neurology $35: 1158,1985$.

15. Roman GC, Roman LN, Spencer PS, Schoenberg BS - An outbreak of spastic jaraparesis along the southern Pactfic coast of Colombia: clinical and epidemiological features. Ann Neurol 14:152, 1983.

16. Roman GC, Roman LN, Spencer PS, Schuenbery BS - Tropical spastic paraparesis: a neuroepidemiological study in Colombia. Ann Neurol 17:361, 1985.

17. Rodgers-Johnson P, Gajdusek DC, Morgan O St C, Zaninovic V, Sarin FS, Graham DS - HTLV-1 and HTLV-III antibodies and tropical spastic paraparesis, Lancet 2:1247, 1985.

18. Scott $\mathrm{HH}-$ An investigation into an acute outbreak of central neuritis. Ann Trop Med Parasitol 12:109, 1918.

19. Spillane JD - Tropical Neurology, Oxford University Press, London, 1973.

20. Strachan $H$ - On a form of multiple neuritis prevalent in the West Indies. Practitioner $59: 477,1897$.

21. Vernant JC, Gessain A, Gout O, Maurs L, Euisson G, Barin F, Calender A, de-Thé G - Paraparésies spastiques tropicales en Martinique: haute prévalence d'anticorps HTLV-I. Presse Med 15:419, 1986.

22. Vernant JC, Maur's L, Gessain A, Barin F, Gout O, Delaporte JM, Sanhadji K, Buisson G, de-Thé G - Endemic tropical spastic paraparesis associated with human T-lymphotropic virus type-I: a clinical and sero-epidemiological study of cases. Ann Neurol 21:123, 1987.

23. Zaninovic V, Biojó R, Barreto P - Paraparesia espástica del Pacífico. Colombla Med $12: 111,1981$. 